\title{
Menthol cigarettes and smoking initiation: a tobacco industry perspective
}

\author{
Kim Klausner
}

\section{Correspondence to}

Kim Klausner, Library and Center for Knowledge Management, 530 Parnassus Avenue, University of California, San Francisco, CA 94143-0840, USA; kim.klausner@ucsf.edu

Received 17 November 2010 Accepted 19 January 2011

\begin{abstract}
Objectives To determine what the tobacco industry knew about menthol cigarettes and the initiation of smoking. Methods Based on Food and Drug Administration staff-supplied research questions we used a snowball sampling strategy to search the Legacy Tobacco Documents Library (http://legacy.library.ucsf.edu) between February and April 2010. Of the approximately 11 million documents available in the LTDL, the iterative searches returned tens of thousands of results. Researchers reviewed 2634 documents and 128 were deemed relevant to one or more of the research questions.

Results The documents show that menthol is added to cigarettes in part because it is known to be an attractive feature to inexperienced smokers who perceive menthol cigarettes as less harsh and easier to smoke and because of their availability from friends and family. Second, the tobacco industry found that some youths smoke menthols because they perceive them to be less harmful than non-menthol cigarettes. A key product design issue concerns whether to increase brand menthol levels to appeal to the taste preferences of long-term menthol smokers or keep menthol levels lower to appeal to inexperienced smokers. Marketing studies showed that the companies carefully researched the menthol segment of the market in order to recruit younger smokers to their brands. The industry tracked menthol cigarette usage by age, gender and race to inform product development and marketing decisions. Conclusions Menthol is a prominent design feature used by cigarette manufacturers to attract and retain new, younger smokers.
\end{abstract}

\section{INTRODUCTION}

There are few studies about menthol cigarettes and smoking initiation by youths. Even though the vast majority of smokers start before age 18, most surveys about initiation do not distinguish between using menthol and non-menthol cigaretttes. ${ }^{1} 2$ Confirming earlier research by Hersey et al, ${ }^{3}$ in 2009 the NSDUH Report stated that novice smokers (those who began smoking in the past year) smoke menthols in greater proportion than more experienced smokers (44.6 vs 31.8\%, respectively). ${ }^{4}$ A 2010 analysis by Fernander et al found that menthol smokers are more likely to be female, younger and from ethnic minority groups. ${ }^{5}$ Using data from the 2005 National Health Interview Survey linked with the Cancer Control Supplement, Cubbin et al did not find that menthol cigarettes encourage the uptake of smoking, but given the disproportionate preference for menthol cigarettes by certain demographic groups, the marketing of menthol cigarettes 'may be responsible for enticing the groups least likely to smoke into this addictive behaviour'. 6

The tobacco industry has geared advertising campaigns for both menthol and non-menthol cigarettes towards youths in order to attract new smokers. ${ }^{8}$ Existing research based on industry documents have addressed some of the reasons why youths may be attracted to menthol, in particular, and how that attraction changes over time. Kreslake et al ${ }^{9} 10$ showed that tobacco companies knew that for new or younger smokers menthol 'masks the harshness and discomfort of inhaling smoke' and smokers prefer a greater proportion of menthol to tobacco as they age. Sutton and Robinson's analysis of Lorillard's marketing strategy for its popular menthol brand, Newport, pointed to the company's use of images and copy embodying 'youthfulness, silliness and fun" to attract younger smokers.

Three studies using industry documents and three based on consumer publications as a data source show how the industry targets African American communities. Gardiner ${ }^{11}$ has thoroughly analysed many factors, mainly perpetuated by the industry, that contribute to the disproportionate use of menthol cigarettes by African Americans, although he does not specifically address initiation on the individual level. One industry tactic is advertising disproportionately in African American magazines. ${ }^{12-14}$ (The industry also advertises heavily in Latino magazines, although to a lesser extent $)^{14}$ Anderson concluded that manufacturers of menthol cigarettes, 'particularly Kool and Newport, aggressively targeted young Black populations with socially relevant messages of ingroup identity'. ${ }^{15}$ And Balbach et al's analysis of RJ Reynolds' ill-fated introduction of Uptown, a menthol cigarette, further documents the targeting of African American communities to increase menthol cigarette sales. ${ }^{12}$

This previous research using industry documents clearly demonstrates that the industry was aware of a preference for menthol cigarettes by novice smokers as well as women and African Americans (overlapping categories) and that they exploited these proclivities to attract and keep loyal users. This paper, specifically focusing on how menthol affects initiation, strengthens these claims by adding more depth to the evidentiary base: over 40 additional documents were found that provide more details and nuance to our understanding of how and why menthol is used by novice smokers.

\section{METHODS}

In this qualitative research study of the digitised repository of previously internal tobacco industry ineme, see about/unlocked.xhtml 
documents, a snowball sampling design was used to search the Legacy Tobacco Documents Library (LTDL, http://legacy.library. ucsf.edu). ${ }^{16}$ We systematically searched the LTDL between 23 February 2010 and 8 April 2010, utilising standard documents research techniques as described in detail in this supplement by Anderson's paper on research methodology. ${ }^{17}$ These techniques combine traditional qualitative methods with iterative search strategies tailored for the LTDL dataset. ${ }^{18}$

The Food and Drug Administration (FDA) supplied research questions, including 'Does menthol make it easier for young or new/inexperienced smokers to start smoking cigarettes?', 'Did current smokers start smoking menthol cigarettes before switching to non-menthol cigarettes?' and 'Did the tobacco industry market menthols to the youth market and what images did they use?' Based on these questions initial keyword searches combined terms related to: menthol, initiation, 'young adult', 'younger adult' and 'starter product'. This first set of keywords and phrases resulted in the development of further search terms and combinations of keywords (eg, 'smoking behaviour', Kool, Newport, Salem, candy, 'soothing effect' and irritation). Documents from all US and international companies were searched although the focus was on menthol use in the USA; document dates were not limited.

Of the approximately 11 million documents available in the LTDL, the iterative searches returned hundreds of thousands of results. Researchers reviewed 3184 documents and a final group of 128 documents were deemed relevant to one or more of the research questions. Memos were written to summarise the relevant documents to identify the representative 50 documents that are cited in this paper.

\section{RESULTS \\ Does menthol make it easier for young or new/inexperienced smokers to start smoking cigarettes?}

\begin{abstract}
Yes, tobacco company business records confirm that menthol is among the design features that companies use to make smoking more attractive to inexperienced, primarily youthful, smokers who find menthol flavoured cigarettes to be less harsh and easier to smoke, more accessible from friends and family or perceive them to be less harmful to their health.
\end{abstract}

As early as the 1960s, tobacco companies conducted studies of smokers that included data about menthol cigarettes. At that time, menthol cigarettes were not particularly associated with youth smoking. A 1961 Philip Morris study about cigarette packaging made no mention of menthol in connection with inexperienced smokers; rather, it found that people viewed menthol cigarettes as more commonly smoked by adult women and 'a change of pace' product for men. ${ }^{19}$

A 1962 RJ Reynolds smoker survey did collect data on age and discovered that a large majority (72\%) of men and women under age 21 had ever smoked menthols and that female smokers under 21 preferred them more than male smokers of the same age $(31 \%$ vs $11 \%) .^{20}$

In the mid-1970s the tobacco manufacturers started conducting focus groups designed specifically to learn why people started smoking menthols. Motivations for obtaining these data varied. Sometimes it was because they were contemplating the introduction of a new menthol brand or brand extension, ${ }^{21-23}$ other times it was to refine their existing menthol product(s) and/or marketing strategies ${ }^{24-26}$ and in some cases it was because they wanted to know why a competitor's menthol market share was growing. ${ }^{27}$

Concerned about the movement towards menthol use among young people and how that movement might affect their
Marlboro franchise, Philip Morris commissioned a study of African American and white smokers under age 24, including an 'under 18' age group (without specifying a minimum age). The study confirmed that menthol was popular among young smokers. $^{28}$

The trend towards menthol use among the young, coming as it did during a time when health concerns about smoking were rising, was encouraging to those companies with large share-ofmarket menthol products because they understood that it was these new, young customers who would grow into loyal consumers in the future. ${ }^{29-31}$ They poured resources into investigating how and why people chose menthols when they were starting to smoke. Some of the studies found that new smokers chose menthol cigarettes because they were easier to smoke, reinforcing the evidence identified by Kreslake. ${ }^{10}$

For example, a 1986 RJ Reynolds memo about a possible new low-level menthol cigarette validated the common popular perception that it takes effort to acclimatise oneself to inhaling smoke.

First-time smoker reaction is generally negative:-foreign taste;harsh/bitter;-adoption requires slow acclimation. Initial negatives can be alleviated with a low level of menthol:- -reduces harshness/ bitterness;- - takes edge off flavour; - previous taste experience; traditional and maintains integrity.

This memo echoed reasons cited in an earlier 1972 RJ Reynolds focus group of young African American smokers that a menthol cigarette, 'is almost invariably regarded as milder than other types, easier on the throat'. 32 Summarising opinions from a 1973 RJ Reynolds study (probably of younger smokers because of references to drug use in the document), advertising agency William Esty Co wrote:

First of all, mentholated cigarettes are considered relatively mild. While some brands are 'strong' in comparison to other mentholated brands, all brands are seen as 'mild' compared to non-mentholated brands. The mentholated cigarette is perceived as soothing in its effect on the throat, a smooth, cool, smoking sensation compared with a harsh, irritating sensation produced by non-mentholated cigarettes....

Several respondents report that they can smoke a mentholated cigarette the first thing in the morning whereas doing this with a non-mentholated cigarette produces unpleasant results, smoking a mentholated one does not. ${ }^{33}$

Three years later, in 1976, a focus group of 18-25 year olds conducted for RJ Reynolds reiterated that they chose menthol after rejecting the 'hot and harsh, dry, chalky' taste of nonmenthols. ${ }^{27}$ A 1978 Lorillard study of 18-20-year old African Americans in Charleston, South Carolina again confirmed that 'Initially (a) menthol cigarette tastes better: (they have a) continuing desire for (the) cool, refreshing taste of menthol over (the) harsh, burning taste of non-menthol'. ${ }^{25}$

A 1979 Philip Morris study (people surveyed were age 18 and over but it did not focus on young adults in particular) made a distinction between 'taste' and 'effects' in the choice of a menthol brand:

The key effects that seem to appeal to menthol smokers are menthol's perceived: Cooling effects; Clean, antiseptic effects; Slightly numbing, anaesthetic effects; Heady, lifting effects

Menthol seems to have some of the properties of a drug, which attract its likers, but repel other smokers. ${ }^{34}$

A 1981 RJ Reynolds study also found that effects or sensations played a role. ${ }^{24}$ But it was not just taste, effect or sensation that 
propelled youths or young adults to smoke menthol cigarettes. The major tobacco companies found a social basis to explain why young smokers used menthol cigarettes-peer or familial influence. Young people under age 18 have a more difficult time purchasing cigarettes and are more likely to share cigarettes obtained from older friends and siblings. If their friends smoke menthols then that is the type of cigarette that is more easily available to them. A report from a 1975 Lorillard focus group of African American and white menthol smokers noted the importance of social factors in their decision to smoke menthols, saying they 'elected to smoke menthol because someone in their family smoked a menthol brand, or close friends smoked a menthol brand, at the time that they began to smoke'. ${ }^{35}$

The Charleston focus group report, referred to earlier, reiterated that 'as far as the prime influences on them regarding their first brand selection:-What their friends smoke is key.To be 'in', smoke what friends smoke.-Easy accessability (sic)/ 'bumming' very common.-What family members smoke provided 'free'/easy access'. ${ }^{25}$ A 1984 Lorillard study of menthol smokers similarly found that

One-half of the respondents smoked a menthol brand as the initial brand they tried because it was the brand that was available in the home or available from friends....

Two-thirds of both the male and female respondents reported that they began buying menthol cigarettes when they first began purchasing cigarettes for themselves, and almost always cited peers as the major influence in their selection of menthol cigarettes at the time. $^{26}$

While the tobacco companies cited ease of smoking and peer/family influences as the predominant reasons why youths smoke menthol cigarettes, in the early 1970s, Philip Morris and RJ Reynolds both found that certain people smoked them because they believed it enhanced the smoking of marijuana. ${ }^{32} 3637$ This connection may have been a passing phenomenon but it was still being reported in the 1990s. ${ }^{38}$

Some manufacturers viewed the decision to smoke menthols as a random or unconsidered event. For example, a 1972 qualitative study of young African American smokers conducted for RJ Reynolds reported that before becoming confirmed menthol smokers the choice of a mentholated cigarette is very often not a conscious choice of this particular type of cigarette.

That is, among our panel members, the mentholated cigarette appeared to be regarded as one of a number of possible alternatives, mentholated and unmentholated. In most cases, there appeared to be no deliberate decision to smoke a mentholated rather than an unmentholated brand; it was simply one of a number of choices. ${ }^{32}$

Imperial Tobacco, Canada's largest tobacco company, also endorsed this view that the initial use of menthol cigarettes was 'largely a matter of circumstance rather than deliberation'. Imperial was also interested in knowing why people choose menthol cigarettes. In a focus group study of adult smokers in 1982 they found that

The means by which people gravitate towards menthol cigarettes, perhaps more than is the case for other choices in the tobacco market, is to a large extent haphazard. It is not, that is, a conscious or deliberate choice. Often, trial of a menthol is occasioned by a cold. It is almost axiomatic among the smoking fraternity that the onset of a head cold is the signal to switch to a menthol, at least for temporary relief. ${ }^{39}$

Other industry studies found that young smokers chose menthol because they found it 'relaxing'33 or 'less harmful' or 'moving away from the problem (of smoking a harmful product)'. ${ }^{39}$ A British American Tobacco study from 1982 found that 'smoking menthols functions as a guilt-reducing mechanism... it manages in some small measure to subtly disguise the sin'. ${ }^{39}$ They also reported that some smokers 'ascrib(e) medicinal properties to the mentholation' and believe that 'menthols are somehow less intrusive or even less harmful than regular cigarettes'. ${ }^{39}$ Brown \& Williamson surmised in 1987 that beginning smokers' familiarity with mint-flavoured confections contributed to their acceptance of menthol cigarettes: 'Menthol brands have been said to be good starter products because new smokers appear to know that menthol covers up some of the tobacco taste and they already know what menthol tastes like, vis-à-vis candy [emphasis added]'. ${ }^{22}$

Menthol cigarettes are not a monolithic category because these brands contain a range of menthol amounts and the quantity has a considerable effect on the cigarette's taste and sensation. The tobacco industry knew that people just starting to smoke prefer cigarettes with a hint of menthol, just enough to take the edge off the tobacco taste. ${ }^{9}$ As smokers age, they begin to favour cigarettes with more menthol taste. This situation creates a dilemma for brand managers: should they keep the menthol level low and risk losing smokers to a higher strength menthol brand or gradually increase the menthol level at the risk of fewer new smokers? ${ }^{22}$ Both RJ Reynolds ${ }^{40}$ and Brown \& Williamson ${ }^{22}{ }^{41}$ recognised this problem. In $1986 \mathrm{RJ}$ Reynolds observed:

once a smoker adapts to smoking a menthol product, the desire for menthol increases over time. A brand which has a strategy of maximising franchise acceptance will invariably increase its menthol level. Thus, once a brand becomes successful, its product will evolve in a manner that is not optimal for younger adult non-menthol smokers/switchers. ${ }^{23}$

\section{In 1987 Brown \& Williamson noted:}

Switching data ... clearly show that KOOL KS (king size) and 100 are not attracting their fair share of starters. Newport, on the other hand, is performing above its fair share. ... one basic product difference exists which can possibly explain part of the reason for KOOL's disparity among starters. Basically, it is that KOOL's menthol level is too high for starters.

The dilemma is that KOOL can't satisfy the needs of both starters and current franchise. Franchise smokers prefer a product providing greater menthol taste than do starters. This paradox isn't easily corrected by just changing KOOL's menthol level, due to the significant risk of losing franchise smokers [emphasis added]. ${ }^{22}$

Companies kept a close watch on competitors' menthol levels, if not in exact measurements because the amounts were closely guarded trade secrets, at least in relative terms. In 1989, RJ Reynolds decided to create a low-menthol extension of its Salem family that would 'position Salem's product line for younger adult smoker growth by offering a product which better addresses their wants' ${ }^{42}$ They test marketed a lower level menthol cigarette in 1990 but it was not until 2003 that RJ Reynolds rolled out Salem Black, a low-level menthol product.

\section{Did current smokers start smoking menthol cigarettes before switching to non-menthol cigarettes?}

Youth tend to smoke brands to which they have access through family or friends but relatively few people switch from menthol to non-menthol cigarettes after they become confirmed menthol smokers. Sometimes younger menthol smokers switched to non-menthol brands, but more often, non-menthol smokers switched to menthol. 
Beginning youth smokers, who generally do not purchase packs on their own, smoke cigarettes that are available to them-those acquired by older friends or family members. While they may prefer a brand or type, they smoke what they can get. It may take some time before a smoker confirms a preference either by refusing to smoke certain brands or types or by buying their own. Even after people become confirmed smokers many go through a period of wavering brand loyalty. A 1984 Philip Morris study concluded "panelists under 25 years old have the largest percentage of switching (except females fifty-five and older smoking $100 \mathrm{~mm}$ menthols)'. ${ }^{43}$ Sometimes younger menthol smokers switched to non-menthol brands, but more often, non-menthol smokers switched to menthol as discussed below.

Companies were more interested in researching brand loyalty than type (menthol or non-menthol) loyalty, but these brand studies provide some evidence about switching. A 1974 Philip Morris report analysed how sales of Brown \& Williamson's Kools to youths affected Philip Morris's Marlboro sales, noting that in the past year fewer young smokers had switched from Kool to Marlboro while the number of those going from Marlboro to Kool remained constant. ${ }^{28}$

A number of the companies, as indicated below, found that menthol smokers had smoked non-menthols, whether as confirmed purchasers or in the initial stages of trying several brands. Because the companies used different research methodologies or did not include sufficient details, the studies found among the industry documents cannot be analysed to determine precisely by year what proportion of menthol smokers started out smoking non-menthols. The 1984 Philip Morris study cited above noted that there was some movement from menthol to non-menthol, but '(l)arger percentages of smokers who switched to a menthol came from a non-menthol than vice-versa'. ${ }^{43}$

While, as noted above, the reasons for switching from non-menthol to menthol cigarettes are varied, having a cold or sore throat seemed to be the predominant reason. ${ }^{27}$ A 1973 RJ Reynolds study found that 'Sometimes respondents saw smoking a mentholated brand as the only alternative to giving up smoking altogether'. ${ }^{33}$

Menthol smokers, in general, liked the taste, and were more apt to switch to another menthol brand rather than a non-menthol if they were dissatisfied with their smoking experience. ${ }^{26}$ A 1982 Imperial Tobacco report also confirmed a similar phenomenon, despite product and market differences in Canada:

Once having made the commitment (to smoke menthols), however, it seems to be an unusually strong one. Even when they try, as they sometimes do, they typically are not able to revert to a non-menthol brand. [Emphasis added.] ${ }^{39}$

\section{Did the tobacco industry market menthols to the youth market and what images did they use?}

\footnotetext{
Yes, ample evidence shows that the tobacco companies collected demographic data (age, gender, and race) on beginning menthol smokers in order to expand each of their market shares. Marketing imagery for menthol brands was geared to reflect themes relevant to a young target audience.
}

Novice smokers find it easier to smoke low-level menthols so tobacco companies with such products have a ready-made customer base because the vast majority of adult smokers start before age $24 .{ }^{44}$ In order to tailor marketing campaigns to capitalise on emerging market trends, companies tracked and analysed smoking behaviour by age, gender and race. ${ }^{45}$ In the late 1960s, companies started to see racial and gender differences among menthol smokers. A 1969 report prepared for American Tobacco Company reported that menthol brands were smoked disproportionately by women and 'non-white' smokers. ${ }^{46}$

This preference for menthol by African Americans and white women among young smokers was observed again by Philip Morris in 1974 (table 1).

Menthols in general do better among the very young, and among very young blacks, almost the entire market is accounted for by Kool, Salem and Newport. ${ }^{28}$ [Emphasis added.]

The same year, Lorillard, interested in expanding its share of the menthol market, considered introducing products to compete with Brown \& Williamson's Kool brand. Lorillard divided product testing sample groups along racial lines, African American and white (each group contained equal numbers of males and females), because their previous research had found that African American and white menthol smokers made smoking decisions differently. Although African Americans smoked menthols to a larger extent than white people, the white people comprised a bigger potential consumer base and they stated that 'it is unlikely that Lorillard would proceed with a product that wins among blacks and loses among whites'. 47

A 1976 Lorillard evaluation of its Newport brand found that they were running third behind Brown \& Williamson's Kool and RJ Reynolds' Salem in the African American market. But, Lorillard also found positive marketing news: Newport was strong among very young smokers.

\begin{abstract}
Strength and growth limited to northeast and north central regions-skews urban, but not black. Franchise very young and heavily female. Young franchise very concerned about alleged effects of smoking on health,- - tend to enjoy smoking less.
\end{abstract}

Newport's SOM (share of market) among smokers 14-17 years old is significantly higher than brand's Total SOM, reflecting strong appeal to young/new smokers. Brand is particularly strong with female smokers in this age group. [Emphasis added.] ${ }^{48}$

From the late 1970s through the 1980s RJ Reynolds' research consistently tracked menthol smoking trends by race, gender and age and saw the increasing popularity of menthols among the young, women and African Americans. ${ }^{44} 49-51$ By 1978 Philip Morris, which did not have a strong menthol product, was concerned about this trend ${ }^{34}$ :

We knew that Blacks, females, and younger smokers were more likely to smoke menthol cigarettes than whites, males, and older smokers. Table 1 shows the magnitude of these differences. ... These differences could have a profound effect on the future growth of the menthol share of the market. We know, for example, that males, whites, and older smokers are more likely to quit smoking than females, Blacks, and younger smokers. ${ }^{52}$

By 1972 Lorillard knew that Newport cigarettes appealed to younger smokers and they debuted their 'Alive with Pleasure'

Table 1 Chart from Philip Morris' a study of smoking habits among young smokers, 1974.

\begin{tabular}{|c|c|c|c|c|c|c|}
\hline & \multicolumn{3}{|c|}{ White } & \multicolumn{3}{|c|}{ Black } \\
\hline & $\overline{18}$ & 19 & $\overline{22}$ & 18 & 19 & $\overline{22}$ \\
\hline & and & to & to & and & to & to \\
\hline & less & $\underline{21}$ & 24 & less & 21 & 24 \\
\hline & 1 & 8 & 8 & 3 & t & $\mathrm{t}$ \\
\hline Smoke a non-menthol & $\underline{63}$ & 69 & 67 & 7 & 17 & $\underline{31}$ \\
\hline Smoke a menthol & $\underline{36}$ & $\underline{31}$ & $\underline{32}$ & $\underline{93}$ & 83 & 66 \\
\hline
\end{tabular}


campaign which relied heavily on images of young people (figures 1 and 2). ${ }^{53}{ }^{54}$ Newport's advertising expenditures increased dramatically as sales grew, going from $\$ 3.96$ million in 1972 to $\$ 6.33$ million in $1975 .{ }^{48}$ There was a self-reinforcing success loop that could be achieved with this approach: marketing to younger smokers with youth-oriented images causes sales to young adults to increase, which gives rise to the perception that the brand is popular which attracts more youthful smokers and encourages a company to expand marketing efforts towards youths. The Alive with Pleasure

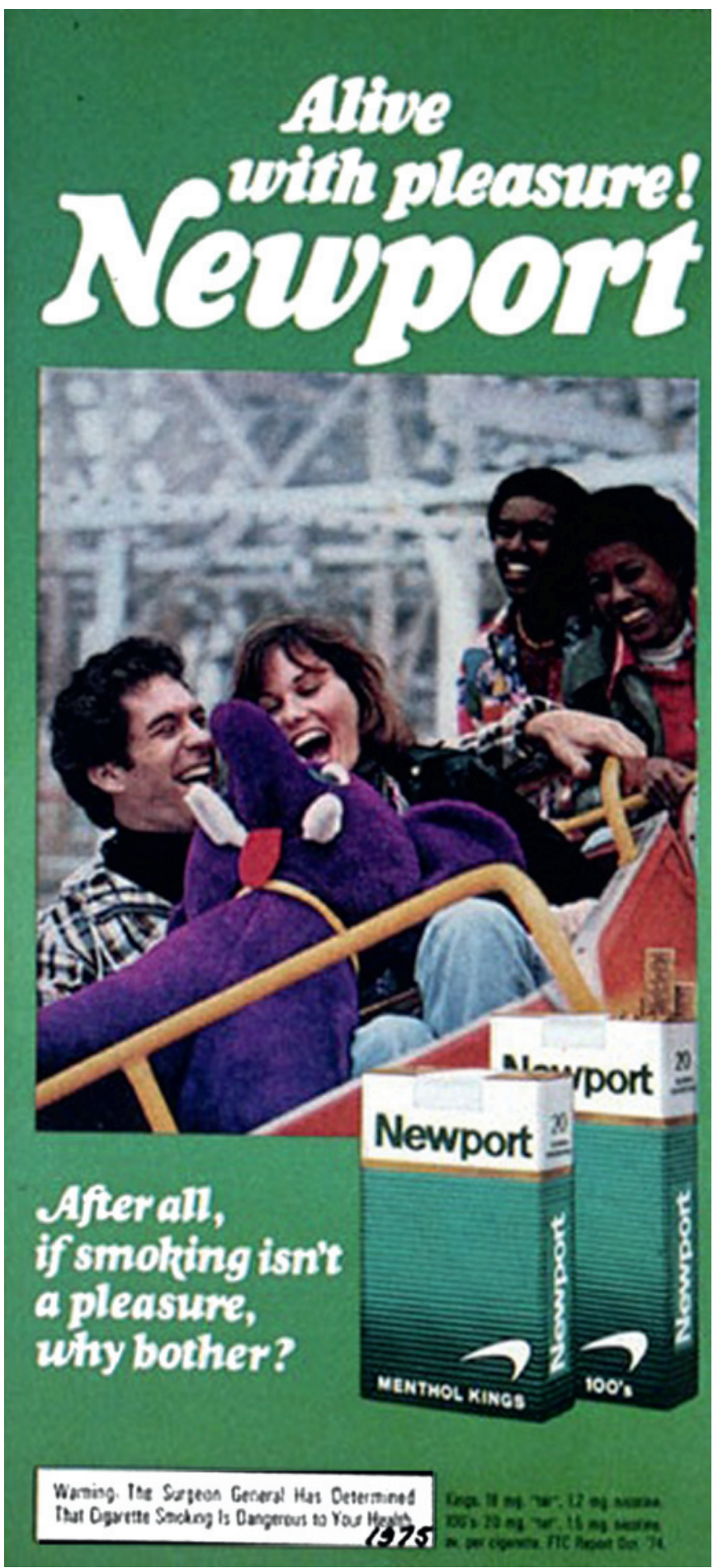

Figure 1 Newport advertisement with image of two young couples enjoying a roller-coaster ride, 1975.

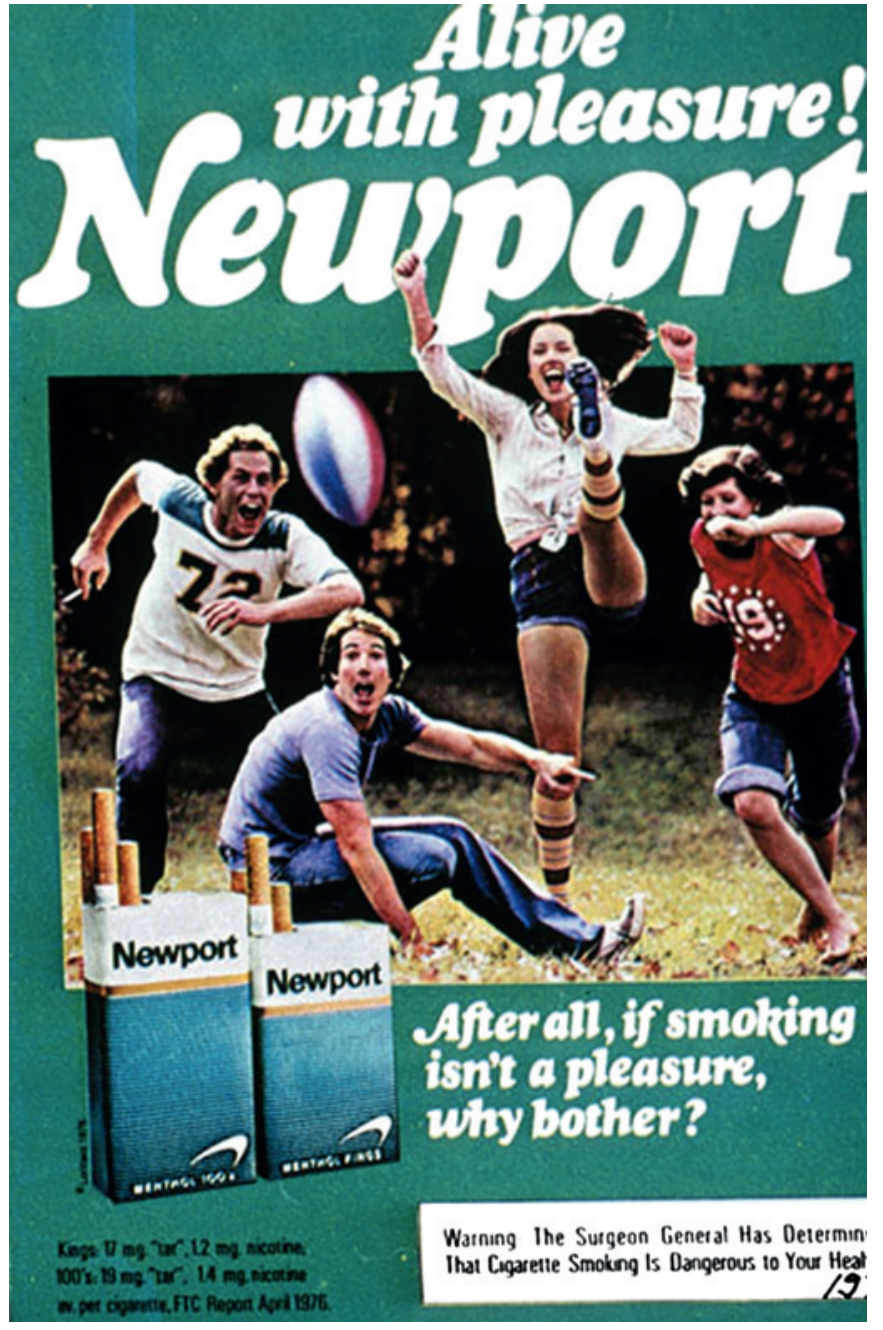

Figure 2 Newport advertisement with image of four young people playing an informal football game, 1976.

campaign was based on the assumption that peer influence largely drove youth smoking choices and the campaign sought to generate and reinforce that peer influence. This observation was later articulated in a 1983 RJ Reynolds report: 'Younger adult primary motivation for brand choice in all product categories is the type of people they see/perceive using the brand'. 55

By 1976, RJ Reynolds saw that Lorillard's strategy was working and that it might negatively impact sales of its Salem brand. They monitored the situation carefully.

Newport's growing acceptance in this area (among 18-25 year olds) is reflected in the positive response to it as a product, to its package and especially to its advertising. ${ }^{27}$

They described the attributes of Lorillard's Newport marketing strategy:

Newport (is) placing increased emphasis on both young female and young male publications reducing older female publications (magazines). Trend is towards younger readers and more men although overall female skew continues.

Newport's promotional plan tends to be directed to its young smokers-youth oriented premiums, inducing pack purchases.

The brand's advertising talks directly to young people-situations, attitude. $^{48}$ 
It took RJ Reynolds until 1982, however, to copy Lorillard's strategy and position Salem as a brand appealing to younger smokers. ${ }^{56} 57$ Their Salem Spirit campaign used images of young people to attract customers (figure 3 ). ${ }^{58}$

The tobacco companies were acutely aware that brand image was particularly important to young adults. ${ }^{26} 57$ RJ Reynolds's 1984 'Younger Adult Smokers: Strategies and Opportunities' showed that

Newport, like Marlboro, relies heavily on its users to provide brand imagery among younger adult smokers. ... Thus, it is no surprise that Newport has become the alternate younger adult identity

brand, for those who don't want to just follow the crowd. ${ }^{44}$

Through the 1990s, Lorillard continued selling Newport to younger smokers using image-based marketing, attributing its success to its 'peer acceptance' and noting that 'Newport smokers perceive other Newport smokers as they do themselves-younger, outgoing, active, happy, warm, friendly, modern, extroverted' 59

While Lorillard knew that its successful marketing campaigns were attracting a larger proportion of young African American smokers than young white smokers, in 1978 the consultant who conducted focus groups of young African American smokers in Charleston, South Carolina, referred to earlier in this paper, recommended to Lorillard that 'Newport should be positioned in the same way to both young Black adult smokers and to Caucasians.-Their needs, feeling(s), brand perceptions are similar regardless of race'. ${ }^{25}$ However, Brown \& Williamson, in

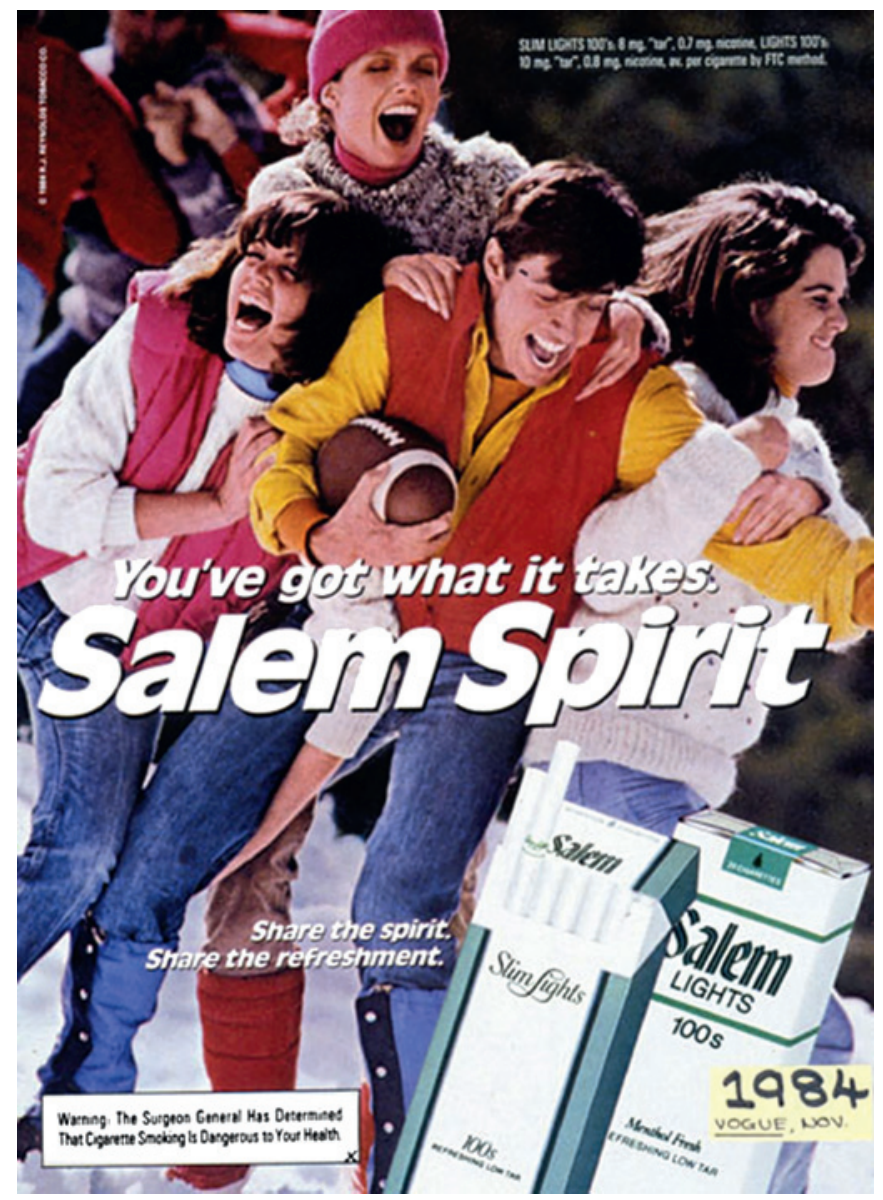

Figure 3 Salem advertisement with image of a young man and three women 'horsing around,' 1984. a 1982 evaluation of their Kool brand indicated that Lorillard did market Newports to the African American community.

Newport, Benson \& Hedges, and More (Benson \& Hedges and More are non-menthol cigarettes) have all targeted user and secondarily product imagery directly at the young KOOL smoker and the Black smoker with successful results in the marketplace. Use of Black media among these competitors has been extensive... 60

RJ Reynolds knew in 1984 that 'younger adult smokers are key to RJR's growth in the Black market and warrant marketing emphasis' 61 and that Black smokers 'appear to be highly responsive to effective advertising spending'. ${ }^{44}$ Advertisements and marketing were developed to attract that market segment (figures 4 and 5). ${ }^{62-64}$

\section{DISCUSSION}

Many youths initiate smoking with menthol cigarettes or switch to menthol within the first few years of smoking. Consistent with earlier studies based on tobacco industry documents, ${ }^{7}$ 9-12 15 we found that the industry identified the main reasons for this behaviour as the relative ease of smoking a menthol cigarette for the uninitiated smoker and its availability from friends and family. The industry also understood that some youths smoke menthols because they perceive them to be less harmful than non-menthol cigarettes, an idea the industry encouraged through its advertising. This perception may be fuelled by the fact that some youths, like adults, ${ }^{15}$ use menthols for the first time when they have a sore throat or

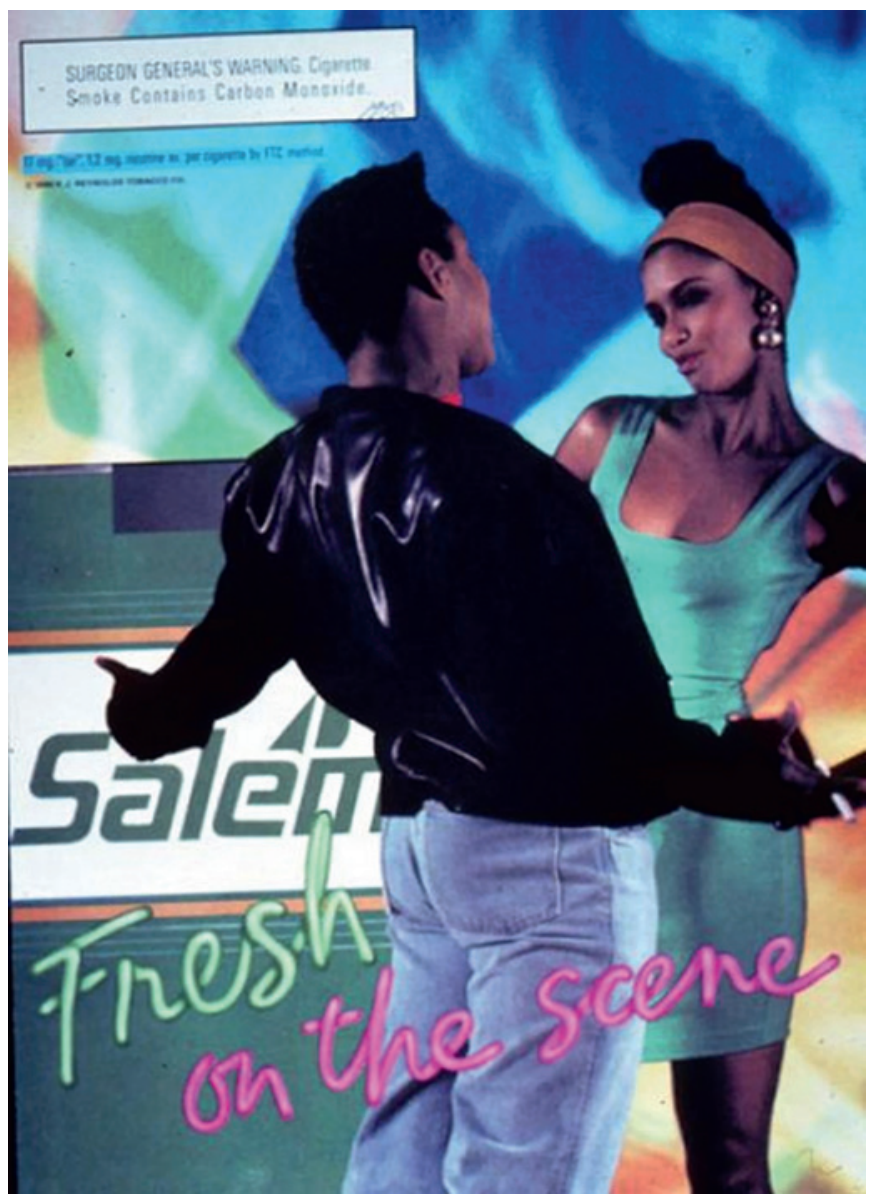

Figure 4 Salem advertisement with image of young, fashionable African American couple, captioned 'Fresh on the scene,'1990. 


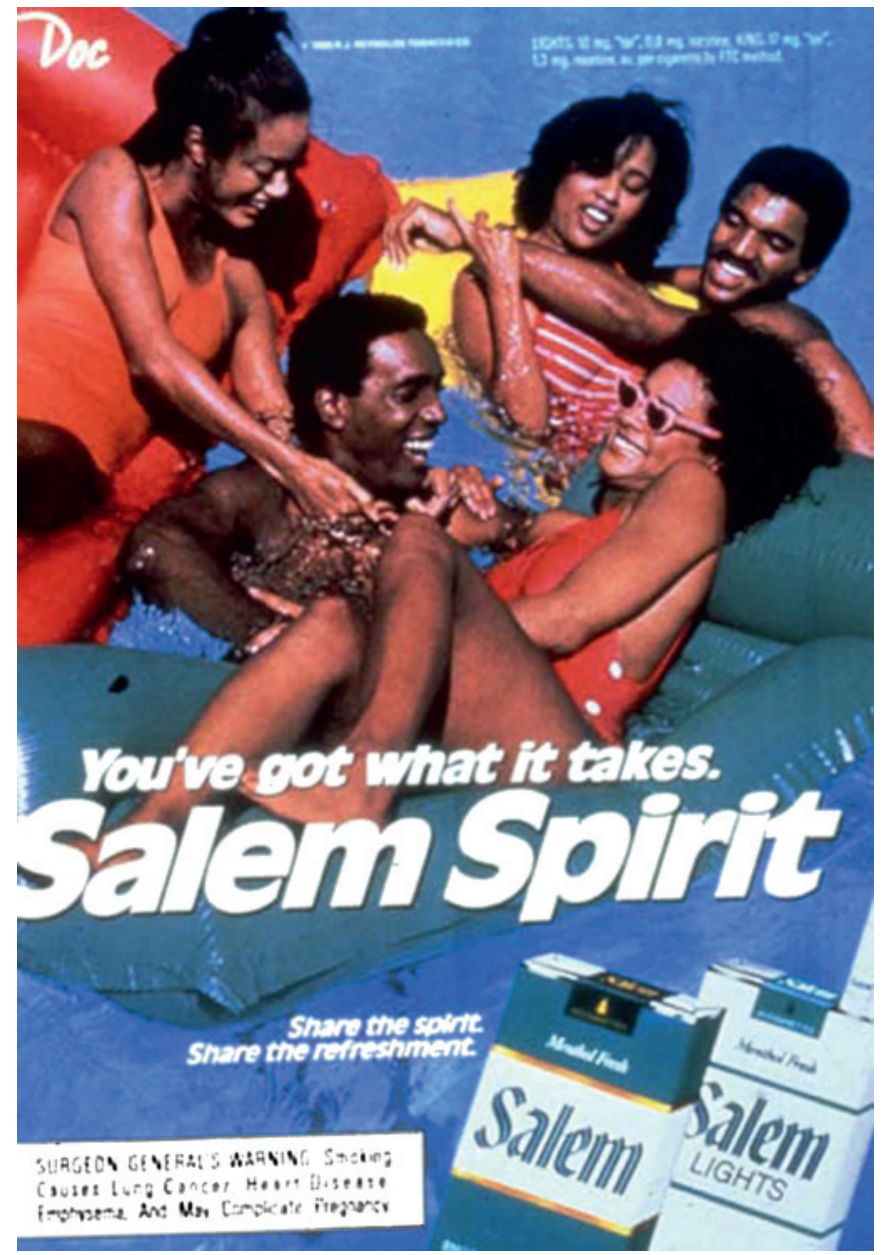

Figure 5 Salem advertisement with image of a group of young African American people playing on a raft in a pool, 1985.

cold because they perceive them to be less irritating than non-menthols.

There is much switching of brands and types of cigarettes in the youth and young adult market, both from menthol to nonmenthol and vice versa. Nonetheless, once smokers have chosen to be menthol smokers either early in life or later, there is very little switching to a non-menthol brand. The qualitative research done by the tobacco companies is consistent with findings of Tauras et a $l^{65}$ who used data from the nationally representative (USA) 2003 and 2006-2007 Tobacco Use Supplements to the Current Population Survey and found that 'smokers did not find menthol and non-menthol cigarettes to be close substitutes for one another' so there will be relatively little switching to nonmenthol cigarettes if menthol is banned by the FDA. Rather, the longer someone smokes menthols, the more they desire a stronger menthol taste and they will tend to switch to a menthol brand with a higher concentration of menthol in the tobacco. The tobacco industry understands this and specifically keeps some brands at a lower menthol:tobacco ratio in order to attract more novice smokers, even at the cost of losing them as they age. Some companies, such as Lorillard and RJ Reynolds, create varieties of menthol brands with varying levels of menthol.

The tobacco industry tracked race and gender in their analyses of the youth and young adult market. They knew that young African American smokers smoke menthols at higher rates than other ethnic/racial groups, and that young women, regardless of race, smoke menthols more than young men. The tobacco

\section{What this paper adds}

- The vast majority of smokers start before age 18 .

- The US Food and Drug Administration is considering a ban on the sale of menthol cigarettes.

- Using additional industry-generated documents, the paper confirms that menthol is added to cigarettes in part because it is known to be an attractive feature to inexperienced smokers who perceive menthol cigarettes as less harsh and easier to smoke and because of their availability from friends and family. Companies keep lower menthol levels in certain brands to appeal to younger smokers and use advertising to attract these market segments.

industry, eager to attract young smokers, designed marketing campaigns that they hoped would appeal to these segments.

While ample evidence was found about the industry's research, product development and testing and marketing of menthol cigarettes, these documents cannot be analysed with the same precision as one would evaluate public health surveys. The documents were written over several decades by employees and consultants from numerous companies. Survey methods and instruments were not always included in the reports so it is frequently difficult to know exactly what was meant by the phrase 'beginning smokers,' for example. It was not clear if the industry author was referring to those who had ever taken a puff of a cigarette or did they mean those who had started to smoke fairly regularly but for less than a year (definitions commonly used in the open literature).

Nonetheless, this study has found considerable additional evidence showing that: many people start smoking menthol cigarettes rather than non-menthols because they perceive that it is easier to inhale the mentholated smoke into their lungs; peers and families influence the brand choice of people under 18 by providing them with access to cigarettes; some smokers choose to smoke menthol cigarettes when they have a cold or sore throat because of their perceived mildness; as smokers age they desire greater and greater amounts of menthol in their cigarettes; and tobacco companies have targeted vulnerable populations such as women, the young and African Americans with marketing for menthol cigarettes.

This evidence suggests that a ban on menthol in cigarettes would result in fewer people smoking cigarettes. Menthol is a prominent design feature used by cigarette manufacturers to attract and retain new, younger smokers. In addition, not only would some current smokers decide to quit rather than smoke non-mentholated cigarettes, but some young people would not make the transition from experimenting with cigarettes to becoming a confirmed smoker. The FDA should ban menthol in cigarettes which will help lower smoking rates particularly among African Americans and women.

Acknowledgements The author thanks Rachel Taketa, MLIS, for meticulous document searching, and Stanton Glantz, PhD for comments on previous drafts; and Karen Butter, ML, Valerie B. Yerger, ND, Stacey J. Anderson, PhD, Phyra M. McCandless, JD, MPH, M. Victoria Salgado, MD and Vera Harrell for other assistance with this research.

Funding This research was supported by the US Department of Health and Human Services Contract HHSN261201000035I.

\section{Competing interests None.}

Provenance and peer review Not commissioned; externally peer reviewed. This peer reviewed paper is based on a longer, more detailed (but not peer reviewed) 
white paper prepared for the US Food and Drug Administration. The full white paper is available at http://escholarship.org/uc/item/9qp7g9s1 and http://www.fda. gov/downloads/AdvisoryCommittees/CommitteesMeetingMaterials/ TobaccoProductsScientificAdvisoryCommittee/UCM228401.pdf.

\section{REFERENCES}

1. Centers for Disease Control (CDC). The Surgeon General's 1989 report on reducing the health consequences of smoking: 25 years of progress. MMWR Morb Mortal Wkly Rep 1989;38(Suppl 2):1-32.

2. Trinidad DR, Gilpin EA, Lee $\mathrm{L}$, et al. Do the majority of Asian-American and African-American smokers start as adults? Am J Prev Med 2004;26:156-8.

3. Hersey JC, Ng SW, Nonnemaker JM, et al. Are menthol cigarettes a starter product for youth? Nicotine Tob Res 2006;8:403-13.

4. Substance Abuse and Mental Health Services Administration, Office of Applied Studies. Rockville, MD: The NSDUH Report: Use of Menthol Cigarettes, 2009. http:// www.oas.samhsa.gov/2k9/134/134MentholCigarettes.htm.

5. Fernander A, Rayens MK, Zhang M, et al. Are age of smoking initiation and purchasing patterns associated with menthol smoking? Addiction 2010;105(Suppl 1):39-45.

6. Cubbin C, Soobader M, LeClere F. The intersection of gender and race/ethnicity in smoking behaviors among menthol and non-menthol smokers in the United States. Addiction 2010:105(Suppl 1):32-8.

7. Sutton CD, Robinson RG. The marketing of menthol cigarettes in the United States: populations, messages, and channels. Nicotine Tob Res 2004;6(Suppl 1):S83-91.

8. Pierce JP, Messer K, James LE, et al. Camel no. 9 cigarette-marketing campaign targeted young teenage girls. Pediatrics 2010;125:619-26.

9. Kreslake JM, Wayne GF, Alpert HR, et al. Tobacco industry control of menthol in cigarettes and targeting of adolescents and young adults. Am J Public Health 2008;98:1685-92.

10. Kreslake JM, Wayne GF, Connolly GN. The menthol smoker: tobacco industry research on consumer sensory perception of menthol cigarettes and its role in smoking behavior. Nicotine Tob Res 2008;10:705-15.

11. Gardiner PS. The African Americanization of menthol cigarette use in the United States. Nicotine Tob Res 2004;6(Suppl 1):S55-65.

12. Balbach ED, Gasior RJ, Barbeau EM. R.J. Reynolds' targeting of African Americans: 1988-2000. Am J Public Health 2003;93:822-7.

13. Barbeau EM, Wolin KY, Naumova EN, et al. Tobacco advertising in communities: associations with race and class. Prev Med 2005:40:16-22.

14. Landrine $\mathbf{H}$, Klonoff EA, Fernandez S, et al. Cigarette advertising in Black, Latino, and White magazines, 1998-2002: an exploratory investigation. Ethn Dis 2005;15:63-7.

15. Anderson S. Marketing of menthol cigarettes and consumer perceptions. Tobacco Control 2011:20(Suppl 2):ii20-ii28.

16. Malone RE, Balbach ED. Tobacco industry documents: treasure trove or quagmire? Tob Control 2000;9:334-8.

17. Anderson S, McCandless $\mathrm{P}$, Klausner $\mathrm{K}$, et al. Tobacco documents research methodology. Tobacco Control 2011;20(Suppl 2):ii8-ii11.

18. Miles MB, Huberman AM, ed. Qualitative Data Analysis: An Expanded Sourcebook. 2nd edn. Thousand Oaks, CA: Sage Publications, Inc, 1994.

19. Opinion Research Corporation. Smoking Behavior and Smoker Motivation-Their Implications for Packaging. Philip Morris, 1961. http://legacy.library.ucsf.edu/tid/jzm76b00.

20. Salem Nat'I Study - Mentholated and Current Brand Pref. Esty-4/62(620400). Salem Cigarettes National Study of Smokers' Experience with Mentholated Brands and of Current Brand Preferences. Part One: Summary of Findings. RJ Reynolds, 1962 http://legacy.library.ucsf.edu/tid/ogb49d00.

21. U.S Exhibit 87,881, Report, "Oualitative Research on Menthol/Nonmenthol Smokers". DATTA: Philip Morris Inc, 1991. http://legacy.library.ucsf.edu/tid/uha46b00.

22. Cantrell D. Kool Isn't Getting The Starters/236. Brown \& Williamson, 1987. http:// legacy.library.ucsf.edu/tid/gas01f00.

23. Low Level Menthol Opportunity Summary. RJ Reynolds, 1986. http://legacy.library. ucsf.edu/tid/eax18c00.

24. Nicholas Research Intl. A Qualitative Study on Salem Packaging. RJ Reynolds, 1981. http://legacy.library.ucsf.edu/tid/vps89d00.

25. Exploration With Smokers of Menthol Brands - Charleston, South Carolina MLP Number 53-2. Lorillard, 1978. http://legacy.library.ucsf.edu/tid/rrp54c00.

26. An Exploratory Study-Younger Menthol Smokers. Research, 1984. http://legacy. library.ucsf.edu/tid/ziq46b00.

27. Sherman Group. Insights into Newport. An Exploratory Study in Brand Perceptions RJ Reynolds, 1976. http://legacy.library.ucsf.edu/tid/fcb49d00.

28. A Study of Smoking Habits Among Young Smokers. Philip Morris, 1974. http://legacy. library.ucsf.edu/tid/lpo93e00.

29. Cigarette Brand Switching Studies. Research, No Date. http://legacy.library.ucsf.edu/ tid/bmw66b00.
30. Teague C. Research Planning Memorandum on Some Thoughts About New Brands of Cigarettes for the Youth Market. Tobacco Institute, 1973. http://legacy.library.ucsf edu/tid/iiu91f00.

31. Product Information. Research, 1978. http://legacy.library.ucsf.edu/tid/yhg56b00.

32. Assoc CR. A Summary of Focus Group Research Among Young Black People on Mentholated Cigarettes. RJ Reynolds, 1972. http://legacy.library.ucsf.edu/tid/ pkt66a00.

33. Esty W. Salem Cigarettes. Attitudes and Behavior With Respect to Mentholated Cigarettes. RJ Reynolds, 1973. http://legacy.library.ucsf.edu/tid/wad39d00.

34. A Study of Smokers' Habits and Attitudes with Special Emphasis on Low Tar and Menthol Cigarettes Volume I. Research, 1979. http://legacy.library.ucsf.edu/tid/ zvt46b00.

35. An Exploratory Study-Menthol Smokers' Perceptions of Irritations From Cigarettes Lorillard, 1975. http://legacy.library.ucsf.edu/tid/dys31e00.

36. Bolton C. Subject: Nicotine. Research, 1972. http://legacy.library.ucsf.edu/tid/ dly76b00.

37. Fountaine R. Rationale for Testing Marlboro Menthol Box. Philip Morris, 1973. http:// legacy.library.ucsf.edu/tid/hag03e00

38. Delman F. Executive Summary ES98-44. Lorillard, 1998. http://legacy.library.ucsf. edu/tid/zmc91b00

39. Project Crawford: Phase I: 7 Group Discussions. British American Tobacco, 1982 http://legacy.library.ucsf.edu/tid/raf36a99.

40. Lawson J, Toben T. New Business Research and Development Report. Low Level Menthol Opportunity Analysis. RJ Reynolds, 1986. http://legacy.library.ucsf.edu/tid/ vad94d00.

41. KOOL Family Utopian Objectives 790000-850000. Brown \& Williamson, 1979. http:// legacy.library.ucsf.edu/tid/lxs40f00.

42. Project GLD. RJ Reynolds, 1989. http://legacy.library.ucsf.edu/tid/lci54d00

43. Levy C, Martin H, Ryan F. 820000-830000 Loyalty and Switching History by Sex, Age Groupings, Market Delivery Images, Companies, and Major Packings. Philip Morris, 1984. http://legacy.library.ucsf.edu/tid/tzd96e00.

44. Burrows DS. Younger Adult Smokers: Strategies and Opportunities. Research, 1984 http://legacy.library.ucsf.edu/tid/tqq46b00.

45. Consumer Research Report: Analysis of Black Smokers. Mangini, 1984. http://legacy. library.ucsf.edu/tid/rgy52d00.

46. Eastman Chemical Products Inc. 1969 Survey Of Cigarette Smoking Behavior And Attitudes, Volume I, Analysis Of Survey Results. American Tobacco, 1969. http:// legacy.library.ucsf.edu/tid/krm54f00

47. Rifon M. Subject: Proposal on the Baron/Blue Ice Menthol Test \#11047. Research, 1974. http://legacy.library.ucsf.edu/tid/kas46b00.

48. Esty W. Newport Cigarettes Business Analysis. RJ Reynolds, 1976. http://legacy. library.ucsf.edu/tid/ksb59d00.

49. Overview I. RJ Reynolds, 1977. http://legacy.library.ucsf.edu/tid/nhr89d00.

50. Gemma L. 1983 (830000) Profile and Usual Brand Share Among Younger Adults. Final Report. RJ Reynolds, 1984. http://legacy.library.ucsf.edu/tid/jgm83d00.

51. Smoking Behavior and Trends among 18-20 year old Smokers. Mangini, 1985 http://legacy.library.ucsf.edu/tid/xcb72d00.

52. Johnston ME Jr. The Demographics of Menthol Smokers. Research, 1978. http:// legacy.library.ucsf.edu/tid/nau46b00.

53. Lorillard. Alive with Pleasure! Newport. Pollay Advertising, 1975. http://legacy. library.ucsf.edu/tid/utc04b00.

54. Lorillard. Alive with Pleasure! Newport. Pollay Advertising, 1976. http://legacy. library.ucsf.edu/tid/osc04b00.

55. New Brands Research. The Younger Adult Smokers of the ' 80 's. RJ Reynolds, 1983. http://legacy.library.ucsf.edu/tid/ixr68d00.

56. Salem Business Review to Executive Management. RJ Reynolds, 1984. http://legacy library.ucsf.edu/tid/qhp25d00.

57. Salem. Coolness Segment/Salem. Situation Analysis. RJ Reynolds, 1982. http:// legacy.library.ucsf.edu/tid/ymt75d00

58. RJ Reynolds Tobacco. You've Got What it Takes. Salem Spirit. Pollay Advertising 1984. http://legacy.library.ucsf.edu/tid/ace04b00.

59. [Re:] Newport Creative Exploratory. Research, 1993. http://legacy.library.ucsf.edu/ tid/ucq76b00.

60. Corporate Conduct. Topic \#17 Safer Cigarette Volume II. Kool Family Executive Summary. Brown \& Williamson, No Date. http://legacy.library.ucsf.edu/tid/ghz31f00.

61. Special Market Analysis: Black, Hispanic, Military. Mangini, 1984. http://legacy. library.ucsf.edu/tid/ihy52d00.

62. RJ Reynolds Tobacco. Fresh on the Scene. Pollay Advertising, 1990. http://legacy. library.ucsf.edu/tid/qce04b00.

63. RJ Reynolds Tobacco. You've Got What it Takes. Pollay Advertising, 1985. http:// legacy.library.ucsf.edu/tid/nhe04b00.

64. Younger Adult Smokers. Mangini. http://legacy.library.ucsf.edu/tid/piy52d00.

65. Tauras JA, Levy D, Chaloupka FJ, et al. Menthol and non-menthol smoking: the impact of prices and smoke-free air laws. Addiction 2010;105(Suppl 1):115-23. 